\title{
Environmental Analysis of Switchgrass on Soil
}

\author{
Gija Geme $^{1, *}$, Christina Dobson-Jones ${ }^{2}$, Brittany Hagenhoff ${ }^{3}$, Scott McKay $^{1}$ \\ ${ }^{1}$ College of Science and Engineering, Natural Resource Research Center, Southern Arkansas University, United States \\ ${ }^{2}$ College of Science, The University of Utah, United States \\ ${ }^{3}$ College of Arts and Sciences, University of Missouri, United States
}

Copyright (C) 2015 by authors, all rights reserved. Authors agree that this article remains permanently open access under the terms of the Creative Commons Attribution License 4.0 International License

\begin{abstract}
Conversion of biomass to fuel is quickly gaining popularity due to its carbon neutral status and the cost volatility of the traditional fossil fuel resources. Biomass feedstocks, such as switchgrass, require minimal fertilizers, labor, and land management. For sustainable switchgrass production to occur, we must understand environmental effects associated with switchgrass, such as any changes soil is undergoing during the growth of switchgrass. This particular study focuses on concentrations of potassium, phosphorus, and nitrogen in soil. Numerous soil samples were taken from four different species of switchgrass in areas with different amounts of nitrogen fertilization. This study found that there was not an overall trend amongst all the soil and switchgrass plots, however there were some similarities within the individual soils and grasses. The soil samples showed that there tends to be an overall decrease in phosphorus, potassium and nitrogen but some of the soil samples showed an increase in phosphorus, potassium and nitrogen content in 2009. Average nitrogen concentrations observed in soil ranged from 2.11-8.99 $\mathrm{g}$ $\mathrm{N} / \mathrm{kg}$ soil and in switchgrass ranged from 3.38-7.67 $\mathrm{g} \mathrm{N} / \mathrm{kg}$ grass. The amounts of phosphorus in soil ranged from $30.7-179 \mathrm{mg} \mathrm{P} / \mathrm{kg}$ soil and in switchgrass ranged from $14.5-52.7 \mathrm{~g}$ of $\mathrm{P} / \mathrm{kg}$ grass. The amounts of potassium in soil ranged from 162-337 $\mathrm{mg} \mathrm{K} / \mathrm{kg}$ soil.
\end{abstract}

Keywords Switchgrass, Nutrients, Soil, Environment

\section{Introduction}

There is a pretty high demand for creating renewable bioenergy crops due to the increase cost of transportation fuels and the risk environmentally dealing with nonrenewable energy. Switchgrass is a hopeful feedstock because of its increased biomass production under certain growing conditions and its sufficient forage and chemical makeup [1].

Switchgrass can also produce high-quality forage with yields ranging from 2 to 5 tons per acre depending on variety, rainfall, soil type, as well as other environmental conditions. The nutrient content of this forage can be as high as 16 percent crude protein, if harvested correctly [2].

There is the possibility of having switchgrass as a "dual purpose" crop: biofuel and forage crop. While switchgrass is planted primarily for biofuels production, there is potential to harvest the early growth through haying or grazing, then managing the remainder of the season's growth for biofuels [2].

Switchgrass is a native warm season, rhizomatous, perennial grass that ranges in height from 3 to 6 feet. It is a bunch grass with flat leaf blades about $1 / 2$ inch wide and 30 inches in length. It is a good cover plant for birds and some small game. It can be used for forage, conservation buffers, streambank stabilization, filter strips and wildlife.

Different varieties of switchgrass are recommended for planting. 'Alamo' switchgrass is highly recommended throughout the southeast. It has been fully tested for conservation uses and is recommended for forage, buffers, wildlife plantings, critical area treatment, shoreline and streambank stabilization and nutrient reclamation. 'Cave-In-Rock' is recommended in the northern portion of the Southeastern Region. Not as good on critical sites as 'Alamo'. It is adapted to lowland and upland sites with good palatability and animal gains. More dormant seed than 'Blackwell' and tends to be slow to establish. It is a good variety for wildlife plantings. 'Blackwell' is not well adapted in the lower southeastern region. It can be used in mixed stands for wildlife plantings. However, it has less forage production than 'Cave-In-Rock'. It is fine stemmed and rust resistant. 'Kanlow' switchgrass is well adapted to a large region of central U.S. and although performs best on lowland soils, it persists and produces on marginal upland soils also. 'Kanlow' flowers earlier than 'Alamo'. 'Kanlow' is used extensively in soil conservation projects especially in low laying wet areas such as streambanks and waterways. It has also been extensively tested for potential biofuel grasses [3].

To minimize fertilizer costs, farmers prefer to reduce crop removal of nutrients from the soil when biomass is harvested. The previous study [4] has shown evidence of nutrient recycling in the field by switchgrass plants and supported the 
concept of a reverse flow of nutrients to soil at the end of the season. Another study [5] has shown that under Mediterranean environmental conditions, the N-P-K content in switchgrass tissues is variable among the various plant organs, while the average N-P-K concentrations in whole plant tissue stand in really low levels during plant mature. Palmer and his coworkers [6] demonstrated that the perennial grasses in their study had low nutrient removal, although giant reed and plume grass often removed significantly more N, P, K and S compared with Miscanthus spp. and switchgrass.

Few data are available on the productivity of different switchgrasses in the Midwest region and thus this study was conducted to examine the influence of key nutrients on different types of switchgrass.

The objective of this study was to monitor, from 2008-2011 at Warrensburg (MO, USA), the nutrient concentrations in soil and switchgrass roots. The nutrient concentrations were also monitored in switchgrass tissue in 2011. Soil and tissue samples were collected to determine the loss of nutrients during the growth of switchgrass plants.

\section{Materials and Methods}

\subsection{Switchgrass Plots}

Soil samples used to analyze nitrogen were from November of 2008, 2009, 2010, and 2011 and tissue samples were from November 2011. Soil samples used to analyze phosphorus were from November 2008, 2009, and 2010 and tissue samples were from November 2008. Soils samples used to analyze potassium were from November of 2008, 2009, and 2010.

The soil was taken from plots of four different types of switchgrass including 'Kanlow' (K), 'Blackwell' (BW), 'Alamo' (A), and 'Cave-in-Rock' (CR). The plant and soil samples were obtained from 36 switchgrass plots. Switchgrass was grown on University of Central Missouri farm.

Soils samples were collected to a depth of $15 \mathrm{~cm}$ with a Hoffer tube (1-cm diameter) from each plot. Three cores per plot were collected, pooled, and analyzed for potassium, nitrogen, and phosphorus.

Biomass samples were collected and dried at $60^{\circ} \mathrm{C}$ in forced air for 48 hours for nutrient analysis.

Each grass had nine plots with different nitrogen amounts added in 2007; three with $0 \mathrm{lbs}$ of nitrogen added, three with $50 \mathrm{lbs}$ of nitrogen added, and three with $100 \mathrm{lbs}$ of nitrogen added (Figure 1). There was no additional nitrogen added through the study. The nitrogen added was in the form of ammonium nitrate and was sprayed at different amounts to different soil plots.

Different switchgrasses were purchased and planted on the plots by the students in the agriculture department. Every fall switchgrass was cut, collected and used to measure for calorie content and NPK values.

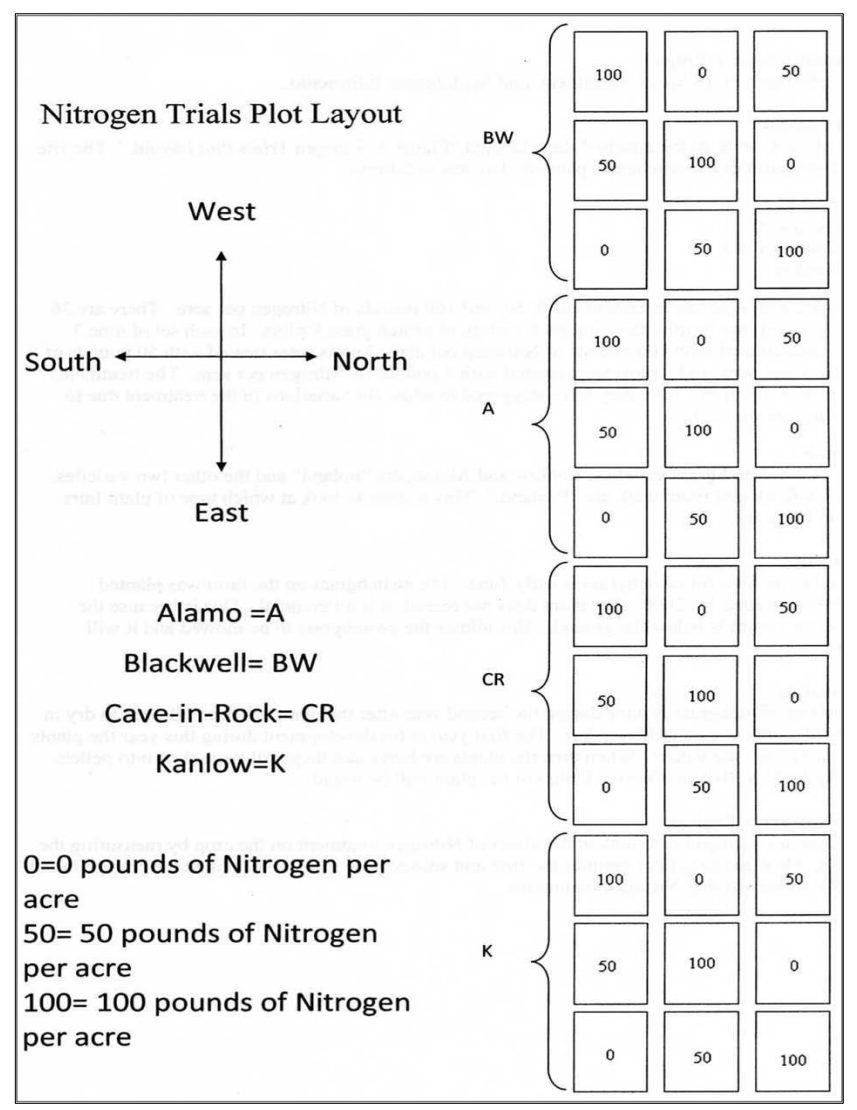

Figure 1. Different switchgrass plots on UCM campus.

\subsection{Reagents}

Unless otherwise stated, all water used was distilled and deionized using a Millipore Milli-Q pure water purification system. The resulting water was of the highest quality and did not have any measurable organic or inorganic impurities. All chemicals were reagent grade or better. The potassium dihydrogen phosphate and potassium chloride standards, nitric, acetic, ascorbic acids, boric and sulfuric acids, hydrogen peroxide, ammonium molybdate, potassium antimony tartrate, ammonium nitrate, ammonium fluoride, EDTA, and sodium hydroxide were purchased from Fisher Scientific Inc. Stock solutions of potassium and phosphorus at a concentration of $1000 \mathrm{mg} / \mathrm{L}$ were prepared by dissolving potassium dihydrogen phosphate and potassium chloride.

Appropriate amounts of the stock standard solutions were added to a $100 \mathrm{~mL}$ volumetric flask and diluted to volume using reagent water to give various concentrations of the working standards.

Two different solutions were prepared for phosphorus analysis. Solution A was prepared by dissolving ammonium molybdate and potassium antimony tartate in reagent water. Both solutions were transferred to a $2 \mathrm{~L}$ flask containing 2.5 $\mathrm{M}$ sulfuric acid and diluted to volume. This solution was stored in the dark at $4^{\circ} \mathrm{C}$. Solution $\mathrm{B}$ was prepared by dissolving ascorbic acid in solution A. This solution was prepared fresh daily.

Trapping solution (boric acid solution) for nitrogen 
analysis was prepared by dissolving boric acid in reagent water containing $0.1 \%$ alcoholic solution of methyl red and $100 \mathrm{~mL} 0.1 \%$ alcoholic solution of bromocresol green. $0.1 \mathrm{M}$ sodium hydroxide solution was added to this solution until a reddish purple tint was observed.

\subsection{Digestion}

\subsubsection{Phosphorus and potassium digestion}

Mehlich 3 extractant stock solution was prepared by dissolving ammonium fluoride in reagent water and adding EDTA to this mixture.

Mehlich 3 extractant was prepared by dissolving ammonium nitrate in reagent water and adding Mehlich 3 extractant stock solution, concentrated acetic acid, $10 \% \mathrm{v} / \mathrm{v}$ nitric acid to this mixture. This extractant was prepared biweekly.

Soil nutrients were extracted using $30 \mathrm{~mL}$ of Mehlich 3 extracting agent and then was shaken for five minutes and filtered [7].

The grass tissue was extracted using $4 \mathrm{~mL}$ of concentrated nitric acid and then was heated on a digestion block for one hour.

\subsubsection{Nitrogen digestion}

The soil and switchgrass was first digested in the Kjeldahl flask where nitrogen was decomposed utilizing sulfuric acid resulting in ammonium sulfate solution using a 6030000 Labconco Micro Digestor.

\subsection{Instrumentation}

\subsubsection{Phosphorus analysis}

The samples were analyzed using a manual colorimetric method. Solution B was mixed with sample and let stand for 10 minutes for color development and then measured at an absorbance of $845 \mathrm{~nm}$ on a Varian Cary 300 Bio UV-visible spectrophotometer [8].

\subsubsection{Nitrogen analysis}

The digested samples were distilled at a rate of 5 $\mathrm{mL} / \mathrm{minute}$. The sample and two rinses of the Kjeldahl flask were loaded into the reaction chamber. $20 \mathrm{~mL}$ of a boric acid receiving solution was placed on the receiving shelf of the Labconco 6500000 RapidStill I distillation unit. Then $20 \mathrm{~mL}$ of a $10 \mathrm{M}$ sodium hydroxide solution was added to the reaction chamber and the sample was distilled for three minutes and the distillate was captured in the receiving solution. The receiving solution was then titrated with a $0.005 \mathrm{M}$ sulfuric acid for quantitation [9].

\subsubsection{Potassium analysis}

The samples were analyzed using Varian 240 atomic emission spectrometer.

\subsubsection{Phosphorus results}

The phosphorus concentrations were calculated using the calibration curves, amount of soil used, and $\mathrm{mL}$ of extractant obtained. The phosphorus in the Alamo soil ranged from 58.8-179 $\mathrm{mg}$ of phosphorus/kg of soil (Figure 2A). The soil with $50 \mathrm{lbs}$ of nitrogen showed the biggest signs of depletion over time, while the soil with $0 \mathrm{lbs}$ and $100 \mathrm{lbs}$ of nitrogen showed a slight decrease in the first year and then slight increase in the second year in the phosphorus content. The phosphorus in the Kanlow soil ranged from 47.0-163 mg of phosphorus/kg of soil (Figure 2B). The soil with 0 and $50 \mathrm{lbs}$ of nitrogen showed a steady depletion of phosphorus while the soil with $100 \mathrm{lbs}$ of nitrogen showed a heavy increase of phosphorus after the first year and then a decrease in phosphorus content after the second year. The phosphorus in the Cave-in-Rock soil ranged from 53.7-162 $\mathrm{mg}$ of phosphorus/kg of soil (Figure 2C). The soil with $0 \mathrm{lbs}$ of nitrogen showed a steady decrease of phosphorus, but the soil with $50 \mathrm{lbs}$ and $100 \mathrm{lbs}$ nitrogen showed an increase in 2009 and a decrease in 2010 in phosphorus content. The Blackwell soil was lowest in phosphorus content (Figure 2D). The Blackwell soil ranged from $30.7-138 \mathrm{mg}$ of phosphorus $/ \mathrm{kg}$ of soil. All plots of the Blackwell showed a steady decrease in phosphorus in all three years. The phosphorus content in the different grass plots was very different from each other in 2008. The Kanlow grass ranged from 49.2-56.2 $\mathrm{g}$ of phosphorus $/ \mathrm{kg}$ of grass. The Alamo grass ranged from 21.1-22.8 g of phosphorus $/ \mathrm{kg}$ of grass. The Cave in Rock grass was the lowest in phosphorus content, ranging from 12.0-17.0 $\mathrm{g}$ of phosphorus $/ \mathrm{kg}$ of grass.
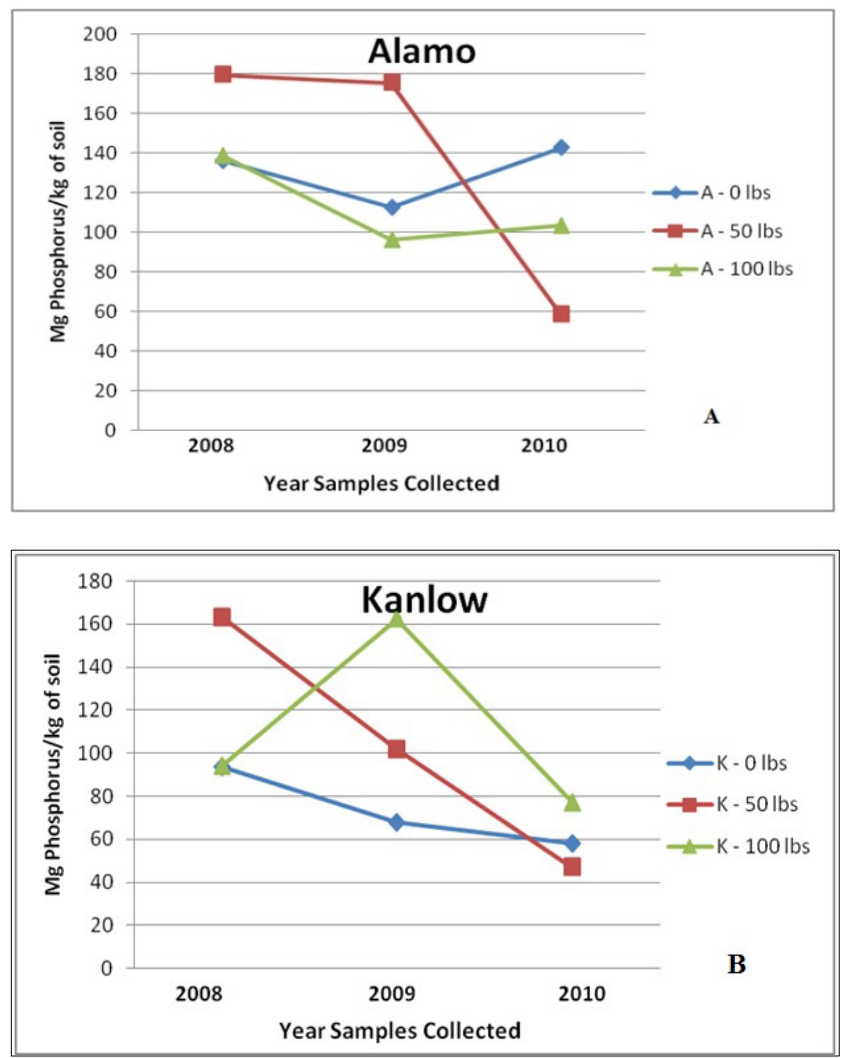

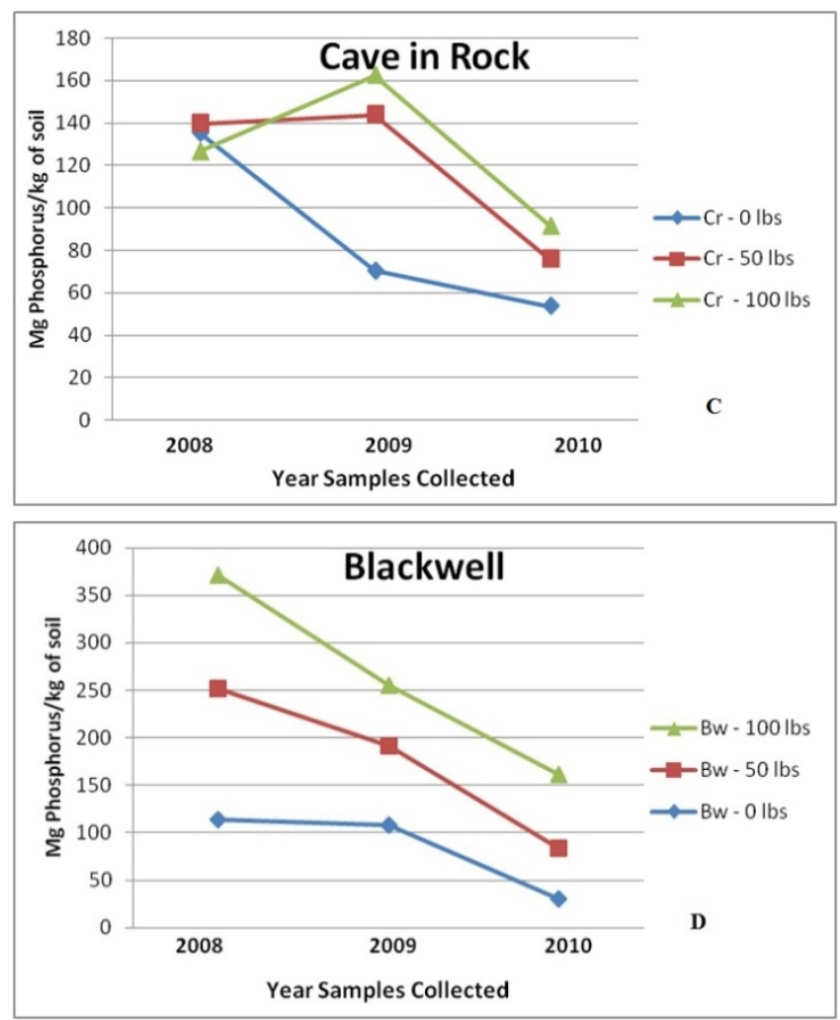

Figure 2 A-D. Phosphorus content in Alamo, Kanlow, Cave-in-Rock, and Blackwell soil.

\subsubsection{Nitrogen results}

The method used for the determining the amount of nitrogen in soil and plants was the Kjeldahl method. The distilled sample was titrated with $0.005 \mathrm{M}$ sulfuric acid to quantify ammonia gas. Through conversion, the amount of nitrogen was calculated. The nitrogen in Alamo soil ranged from 2.11-6.44 g of nitrogen $/ \mathrm{kg}$ of soil (Figure 3A). Alamo soil had a varying trend with neither an increase nor decrease in overall nitrogen content. However, there was obvious spike in nitrogen content in 2009. The nitrogen in the Kanlow soil ranged from 2.83-6.71 g of nitrogen $/ \mathrm{kg}$ of soil (Figure 3B). Overall, the decrease of nitrogen content was observed over the four year period for all of the soils. However, there was a minimal change in nitrogen in the years of 2010 and 2011. The nitrogen in the Cave-in-Rock soil ranged from 2.86-8.99 $\mathrm{g}$ of nitrogen $/ \mathrm{kg}$ of soil (Figure $3 \mathrm{C})$. The nitrogen decreased from 2008-2011, however, there was increase in nitrogen content in 2009. The soil 100 lbs of nitrogen had the highest nitrogen content overall. Also Cave-in-Rock soil had higher nitrogen content than other soil. The nitrogen in the Blackwell soil ranged from 2.56-4.91 g of nitrogen $/ \mathrm{kg}$ of soil (Figure 3D). Blackwell soil appeared to have decreasing nitrogen content with a slight increase in 2011. There was also some nitrogen increase observed in 2009 for the soil with $0 \mathrm{lbs}$ nitrogen. Overall, the Blackwell and Alamo soils were the poorest in nitrogen content. The applied nitrogen did not affect significantly total nitrogen content in the soils. The nitrogen content in the different grass plots was very different from each other in 2011. The Kanlow grass ranged from
6.54-7.67 $\mathrm{g}$ of nitrogen $/ \mathrm{kg}$ of grass. The Alamo grass ranged from 3.85-7.11 $\mathrm{g}$ of nitrogen $/ \mathrm{kg}$ of grass. The Cave-in-Rock ranged from 4.72-5.49 $\mathrm{g}$ of nitrogen $/ \mathrm{kg}$ of grass. The Blackwell grass ranged from 3.38-5.56 $\mathrm{g}$ of nitrogen $/ \mathrm{kg}$ of soil. All of the grasses had higher nitrogen content than the soils, however no trends were observed.
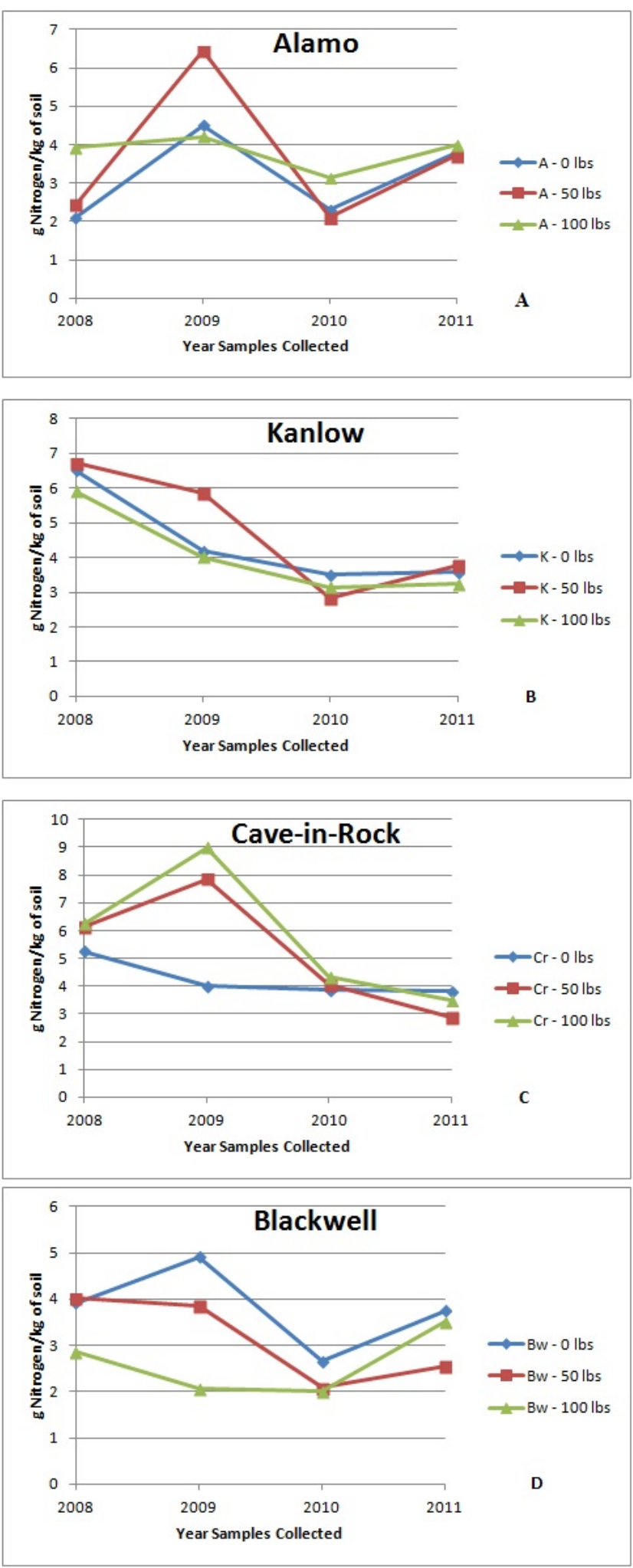

Figure 3A-D. Nitrogen content in Alamo, Kanlow, Cave-in-Rock, and Blackwell soil. 


\subsubsection{Potassium results}

The potassium concentrations were calculated using the calibration curves, amount of soil used, and $\mathrm{mL}$ of extractant obtained. The potassium in Alamo soil ranged from 162-312 $\mathrm{mg}$ of potassium $/ \mathrm{kg}$ of soil (Figure $4 \mathrm{~A}$ ). The soils with applied nitrogen had increase in potassium from the first year to the third year with a spike during the second year. However, soil with $0 \mathrm{lbs}$ of nitrogen applied had steady decrease of potassium during the three year period. The potassium in Kanlow soil ranged from 201-337 mg of potassium $/ \mathrm{kg}$ of soil (Figure 4B). All of the soils showed decrease of potassium during the three year period. However, there was some increase in potassium during second year for the soils with 0 and $100 \mathrm{lbs}$ of nitrogen. The potassium in Cave-in-Rock soil ranged from $168-327 \mathrm{mg}$ of potassium $/ \mathrm{kg}$ of soil (Figure 4C). The steady decrease of potassium was observed from the first to the third year with a spike in the second year. The Cave-in-Rock soil was second the most depleted soil with respect to the potassium concentration, particularly 50 and $100 \mathrm{lbs}$ of nitrogen plots. The potassium in Blackwell soil ranged from $162-251 \mathrm{mg}$ of potassium $/ \mathrm{kg}$ of soil (Figure 4D). The concentrations of potassium decreased within the first three years for soils with 50 and $100 \mathrm{lbs}$ of nitrogen. Similar trend was observed for the soil with $0 \mathrm{lbs}$ of nitrogen; however, there was small increase in potassium content during the second year. The Blackwell soil was the most depleted in potassium after the third year of growth.
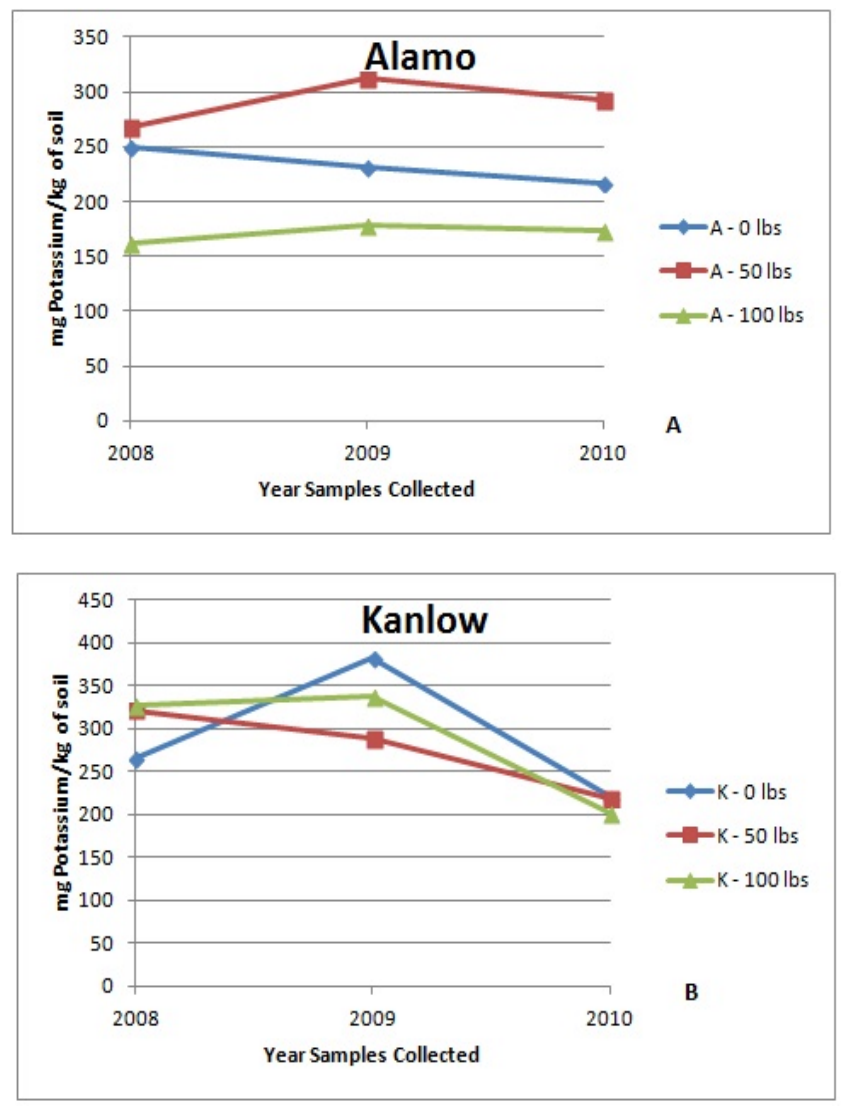
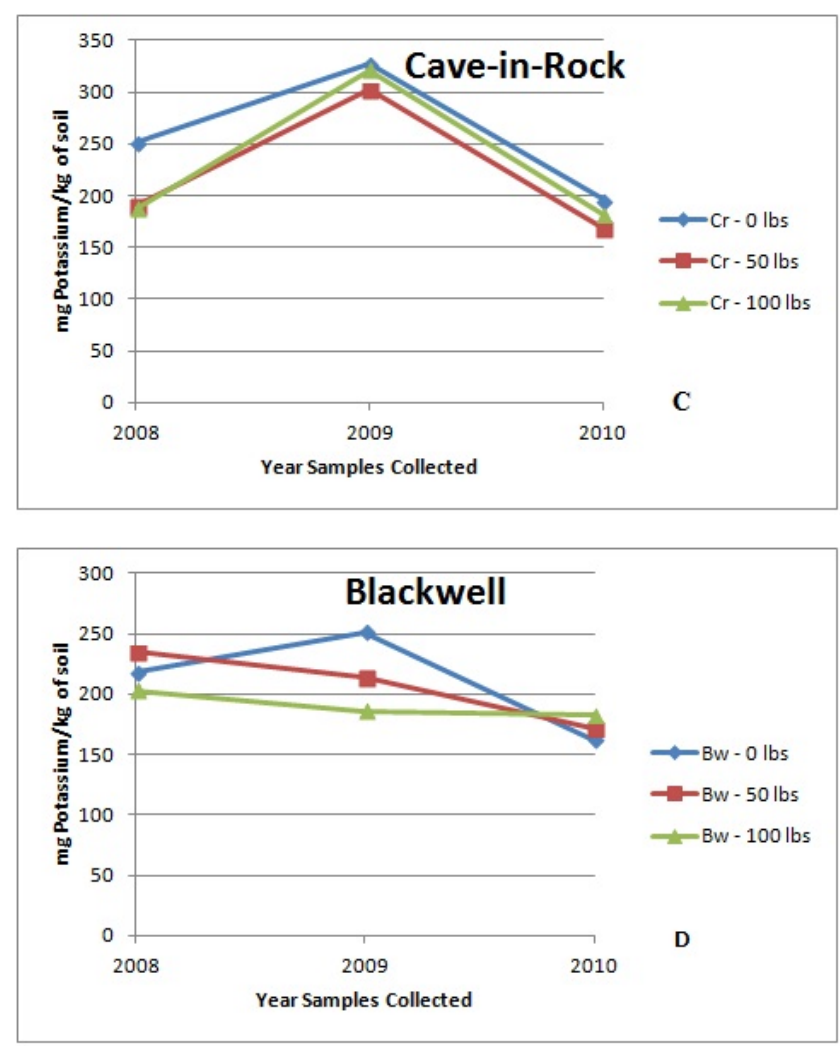

Figure 4A-D. Potassium content in Alamo, Kanlow, Cave-in-Rock, and Blackwell soil.

\section{Discussion}

The data on soil nutrients was needed to provide some evidence for minimal requirements and for efficient use of key nutrients. Not surprisingly, the concentrations of major nutrients in soil samples decreased as expected. However, most of the soil samples experienced increase in nutrients in 2009. Weather conditions during the growing season varied between the four years. The first two years had precipitation above average and years three and four had considerably lower precipitation. It is also possible that the rainfall affected the nutrients present in the soil. The temperatures were also lower than normal temperature during the first two years of study and higher than normal temperatures were observed during the third and fourth year of the study. The previous studies have shown that switchgrass does not develop foliage and moisture that has accumulated over winter in the soil profile and can often sustain growth without drought stress [10]. Thus, not as many nutrients are being used and accumulations of them are observed in the soil.

The amounts of phosphorus in soil ranged from 30.7-179 $\mathrm{mg}$ of phosphorus $/ \mathrm{kg}$ of soil. Similar study performed on Alamo switchgrass showed that phosphorus levels were between 2 to $15 \mathrm{mg} / \mathrm{kg}$ [11]. This study observed higher phosphorus levels; the lowest phosphorus levels were for the Cave-in-Rock and Kanlow soils that were also the best producing soils for the switchgrass. There has been study 
that have shown that soil phosphorus level of "low-plus" (8 $\mathrm{mg} / \mathrm{kg}$ ) was more than adequate based on comparisons across different crops [12]. Within three year period, phosphorus levels in soil decreased between 40-60\%. Based on the data, for Kanlow and Cave-in-Rock soils, it would take another 2-3 years to reach low phosphorus levels. Blackwell and Alamo soils were poor in switchgrass and thus phosphorus did not decline so fast in these soils.

The amounts of potassium in soil ranged from 162-337 $\mathrm{mg}$ of potassium $/ \mathrm{kg}$ of soil. Similar study performed on Alamo switchgrass showed that potassium levels were between 33 to $146 \mathrm{mg} / \mathrm{kg}$ in the one-cut system and 20 to 73 $\mathrm{mg} / \mathrm{kg}$ in the two-cut system [11]. This study also showed that the two-cut systems produces higher switchgrass yields but thus was depleting the soil potassium pool. The study performed at the UCM farm used one-cut system of switchgrass. One study reported that soil potassium and tissue potassium concentrations provide support for the use of $100 \mathrm{mg} / \mathrm{kg}$ as the soil test level below which potassium fertilizer application is recommended in perennial ryegrass [13]. However, a soil test value of "medium-minus" for $\mathrm{K}$ (44 mg/kg) was deemed inadequate by Virginia Tech soil testing laboratory [11]. Soil at the UCM farm was rich in potassium and a very small decrease over a three year period was observed on average, potassium decreased by only $20 \%$. For a long term growth of switchgrass, no additional potassium needs to be added.

Cave-in-Rock and Blackwell soils were depleted in nitrogen over four year period but again they were the ones that produced the most biomass. However, it did not seem that there was a big effect on the applied amount of nitrogen on soil. After the four years, Cave-in-Rock soil had about 3 $\mathrm{g}$ of nitrogen $/ \mathrm{kg}$ of soil and Kanlow soil had about $4 \mathrm{~g}$ of nitrogen $/ \mathrm{kg}$ of soil. It was also observed that after the second year, nitrogen content dropped almost by half and leveled out in the soil. It seems that application of $50 \mathrm{lbs}$ and $100 \mathrm{lbs}$ of nitrogen yielded the same results. It is suggested that nitrogen should be reapplied every two years with minimum of $50 \mathrm{lbs}$ for successive growth of switchgrass. With respect to the grasses, Cave-in-Rock and Kanlow grasses had significantly higher nitrogen content than that of the soil and in some cases it was even doubled but again these grasses yielded higher amounts of switchgrass and were better suited for the Midwest region.

\section{Conclusions}

Nitrogen, phosphorus, and potassium are the primary macronutrients for plants in soil. Determining and monitoring the concentrations of these nutrients are important for sustainable and inexpensive alternative fuel source or high-quality forage. By monitoring the uptake of these nutrients for 3-4 years, makes it possible to find the optimal level of fertilizer needed to have maximum biomass harvest and forage. Overall, this study showed that Cave-in-Rock and Blackwell switchgrass were the best suited for the Midwest region. This three-year study has shown that Cave-in-Rock and Blackwell switchgrass, when harvested once at the end of the growing season, produced high yields with minimal inputs. During the three year period, all of the macronutrients decreased as expected with interesting increase during the second year. However, they never depleted soil so much that addition of these macronutrients would be necessary. There was not an overall trend amongst all the soil and switchgrass plots, however there were some similarities within the individual soils and grasses. The results also showed that there was not a significant difference if either $50 \mathrm{lbs}$ or $100 \mathrm{lbs}$ of nitrogen was applied. It is suggested that $50 \mathrm{lbs}$ of nitrogen should be applied and could be applied every three years. It is also suggested that the soil $\mathrm{pH}$ should be maintained during the period Switchgrass was grown.

\section{Acknowledgements}

The authors gratefully acknowledge the University of Central Missouri and its Department of Biochemistry, Chemistry, and Physics and their Center for Alternative Fuels and Environmental Sciences (CAFES). The authors would also like to thank the Society for Analytical Chemists of Pittsburgh grant and UCM internal grant. Finally, the authors are thanking Southern Arkansas University and the Natural Resource Research Center.

\section{REFERENCES}

[1] M. Marra, T. Keene, J. Skousen, T. Griggs. Switchgrass yield on reclaimed surface mines for bioenergy production, Journal of Environmental Quality, Vol. 42, 696-703.

[2] R. Lemus, Establishing and managing switchgrass as a forage, Online available from http://www.uwex.edu

[3] USDA Natural Resources Conservation Service, Plant sheet, Online available from http://www.nscs.usda.gov

[4] R. Holou, G. Stevens, V. Kindomihou. Return of aboveground nutrients by switchgrass into the surrounding soil during senescence, Biofuels, Vol. 4, No. 2, 169-183.

[5] K. Giannoulis, N. Danalatos. Switchgrass (Panicum virgatumL.) nutrients use efficiency and uptake characteristics, and biomass yield for solid biofuel production under Mediterranean conditions, Biomass \& Bioenergy, Vol. 68, 24-31.

[6] I. Palmer, R. Gehl, T. Ranney, D. Touchell. Biomass yield, nitrogen response, and nutrient uptake of perennial bioenergy grasses in North Carolina, Biomass \& Bioenergy, Vol. 63, 218-228.

[7] D. L. Sparks. Methods of Soil Analysis Part 3 - Chemical Methods, Soil Science Society of America, Inc., Madison, 1996.

[8] H. Mills, J. B. Jones. Plant Analysis Handbook II, 
Micro-Macro Publishing, Athens, 1996.

[9] J. J. Benton. Kjeldahl Method for Nitrogen Determination, Micro-Macro Publishing, Athens, 1991.

[10] I. Rao, V. Borrero, J. Ricaurte, R. Garcia, M. Ayarza. Adaptive attributes of tropical forage species to acid soils. II. Differences in shoot and root growth responses to varying phosphorus supply and soil type, Journal of Plant Nutrition, Vol. 19, 323-352.
[11] R. Lemus, D. Parrish, D. Wolf. Nutrient uptake by 'Alamo' switchgrass used as an energy crop, Vol. 2, 37-50.

[12] N. Hue, H. Ikawa, X. Huang. Predicting phosphorus requirements of some Hawaii soils, University of Hawaii at Manoa, Agronomy Soils AS, Vol. 2, 1-4.

[13] J. Hart, N. Christensen, R. McReynolds. Potassium and production of perennial ryegrass for seed - Part 1, Oregon State University: Corvallis, OR, Crop Soil News/Notes, Vol. 17, No. 7, 9-11. 